\title{
The epidemiology of thyroid cancer in the Czech Republic in comparison with other countries
}

\author{
Jindrich Lukas ${ }^{\mathrm{a}}$, Jiri Drabek ${ }^{\mathrm{b}},{\text { David Lukas`, Ladislav Dusek }{ }^{\mathrm{d}} \text {, Jiri Gatek }}^{\mathrm{e}}$
}

\begin{abstract}
Background. Thyroid cancer includes a broad spectrum of tumours with different prognoses. The global incidence has been increasing in recent years. Variables affecting its etiology are dietary, especially iodine intake and to a lesser extent selenium, environmental, like - ionizing radiation and, increased TSH level. These factors interplay with epigenetic and genetic changes within the cell. This review article presents thyroid cancer epidemiology, describes its main characteristics and the influence of environmental and lifestyle risk factors in the Czech Republic in comparison with other countries.
\end{abstract}

Methods and Results. An epidemiological study of Czech patients with malignant thyroid carcinoma was made on the basis of the National Oncologic Registry (NOR) and Czech Statistical Office data summarized on the web portal SVOD. The data were compared with international data from the project GLOBOCAN 2008 Cancer Incidence and Mortality Worldwide. Apart from risk factors, prognostic factors with effect on patient survival were also analyzed. The survey showed that the incidence of thyroid cancer has been steadily growing in the Czech Republic. Since the beginning of the 1980s, it has increased 4 fold. It has a higher incidence than most other European countries but it is ranked with countries with an average and decreasing mortality. Obviously, the improved detection methods do not explain the growing incidence. The highest incidence is found for papillary carcinoma (PTC), now over $80 \%$ of cases. For follicular and medullar cancers, the incidence has not increased and for anaplastic carcinoma there is a slight decrease. Women over 40 years of age constitute the highest risk group.

Conclusions. There are a number of reasons for these trends, such as improved diagnostic techniques using ultrasound and FNAB and more radical surgery. There are also dietary/environmental factors (iodine deficiency and to a lesser extent selenium), nitrates, polychlorinated biphenyls, increased ionizing radiation, and prolonged increase in TSH. The prognosis of patients with DTC depends on the age at the time of diagnosis. A favorable prognosis also depends on timely detection.

Key words: carcinoma of thyroid gland, epidemiology, risk factors

Received: April 29, 2012; Accepted: August 22, 2012; Available online: November 2, 2012

http://dx.doi.org/10.5507/bp.2012.086

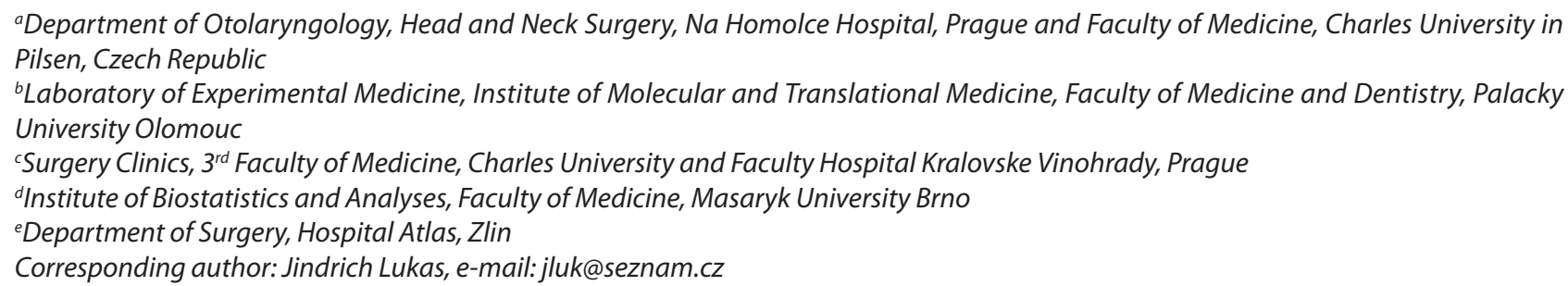

\section{INTRODUCTION}

Thyroid tumors represent only 1 to $1.5 \%$ of all malignant tumors in humans; however, they are the most common malignant tumors of the endocrine organs (> $92 \%$ ) (ref. ${ }^{1}$ ). In the last 3-4 decades, their incidence worldwide has been steadily increasing, and this tendency is noted in the Czech Republic. According to the National Oncologic Registry (NOR), in the Czech Republic, more than 800 new cases of malignant thyroid cancers were diagnosed annually in the period 2004-2008.

Thyroid cancers include a broad spectrum of tumors with different epidemiology, biological activity and prognosis. They occur in all age groups, and between the ages 15 to 45 , they are among the 5 most common types of carcinomas $^{2,3}$. Women are affected four times more often than men. Histologically, they can be divided into differentiated carcinomas (DTC), anaplastic thyroid carcinoma (ATC), medullary thyroid carcinoma (MTC), and less frequently lymphomas or metastases of other malignant tumors.

DTCs grow from follicular thyroid cells responsible for the production of colloids and hormones. They are further subdivided into papillary thyroid carcinoma (PTC) and follicular thyroid carcinomas (FTC). The prognostic factors for well-differentiated carcinomas are related to age, sex, and disease spread at the time of surgery.

ATC usually arises from a well-differentiated carcinoma ${ }^{4}$, and is one of the most aggressive cancers. MTC is a tumor of the thyroid parafollicular $\mathrm{C}$ cells that secret calcitonin. MTC is much more aggressive than DTC; it 
is accompanied by nodular metastases in more than $50 \%$ of cases $^{2,3}$.

Other malignant tumors also metastasize into the thyroid and worsen the prognosis: by a direct growth of squamous cell carcinoma of larynx, hypopharynx and esophagus. Further, there are hematogenously spread metastases (lung, kidney, and breast carcinomas), malignant melanoma and retrograde lymphatic spread. A malignant lymphoma, B-cell non-Hodgkin's lymphoma which has been confirmed to be coincident with Hashimoto's thyroiditis ${ }^{5,6}$, can also be found in the thyroid. Any node in the thyroid, revealed in patients with a history of cancer even after a long period without any local recurrence, is regarded as possible metastasis.

Improvements in diagnostic technique, especially ultrasound-guided fine-needle assisted biopsy (FNAB) and measurement of serum thyreoglobulin, have resulted in the earlier diagnosis of the clinical manifestations of DTC. The detection of less advanced tumour stages leads to less aggressive and better tolerated treatment methods with significantly better prognosis, in the place of advanced stages requiring aggressive treatment ${ }^{3}$. It is often found accidentally during ultrasonographic examination of the neck. However, malignant thyroid carcinoma requires multidisciplinary cooperation during the diagnosis and treatment as well as lifelong monitoring of such patients.

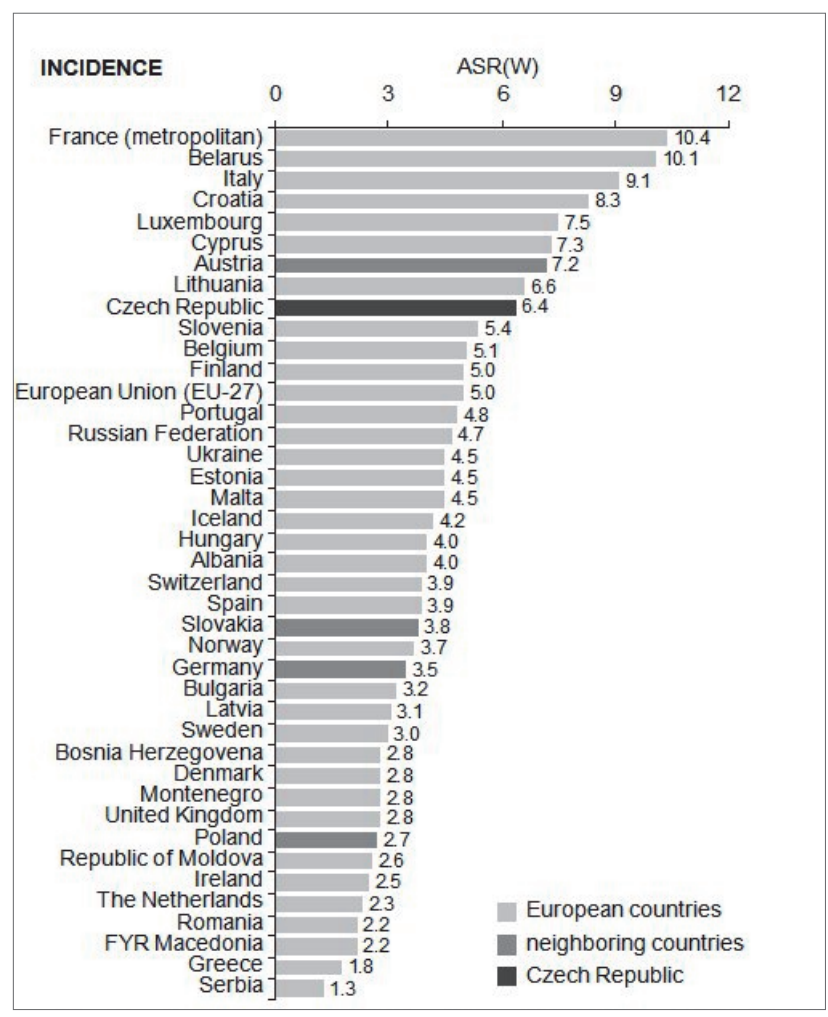

Fig. 1. Comparison of the incidence of malignant thyroid cancers in European countries.

Ferlay J, Shin HR, Bray F, Forman D, Mathers C and Parkin DM. GLOBOCAN 2008 Cancer Incidence and Mortality Worldwide: IARC Cancer Base No [Internet]. Lyon, France: International Agency for Research on Cancer; 2010 Available from http://globocan.iarc.fr

\section{INCIDENCE}

The increased incidence of thyroid cancers affects all races and ethnic groups globally ${ }^{1,7}$. The most common form is papillary carcinoma, constituting about $85 \%$ of all cases $^{1-3}$. Davies, Welch et al. assume that this is due to the increased detection of small $(<1 \mathrm{~cm})$, initial forms of cancer - papillary microcarcinomas (PTMC) (ref. ${ }^{1,2,7}$ ). An increase in the incidence of PTMC has been found in many European countries and ranges from 5.3\% (Switzerland) to $155.6 \%$ (France) in the last 2-3 decades. Similar figures have been reported in the USA. In 1975, the thyroid carcinoma incidence totaled 4.9 cases/100 000 inhabitants/ year, while in 2006 it was 11.0 cases/100 000 inhabitants/ year (ref. ${ }^{8,9}$ ). The Czech Republic occupies the $9^{\text {th }}$ place worldwide with an incidence of 6.4 malignant thyroid carcinoma cases calculated in age-standardized rate -world (ASR-W) (Fig.1) $\left(\right.$ ref. $\left.^{10}\right)$. The incidence of the other two carcinoma types, FTC 10\% (ref. ${ }^{3}$ ) and MTC 5\% (ref. ${ }^{3}$ ), has not changed while for ATC a slight decrease has been found. The incidence is 1 to $2 \%$, $\left(\right.$ ref. $^{4}$ ) over the same period of time.

There are geographical differences in the incidence of thyroid cancer both between countries and, regions and districts within countries (Fig. 1). For example, in contrast to the generally worldwide increase incidence, a decrease has been reported in Sweden - of 18\% in both sexes, in Norway of $5.8 \%$ and in Spain of $25.9 \%$ in women ${ }^{7}$.

In the Czech Republic, there has been an ongoing growth in the incidence of malignant thyroid neoplasms since the 1950s. In 1984, 239 new thyroid carcinomas were diagnosed, in 1994 there were 339 new cases ${ }^{11}$, 2003: 400 new cases ${ }^{12}$; and in 2007: 500 new cases ${ }^{13}$. The data of the National Oncological Registry of the Czech Republic show that in 2004 - 2008, the average incidence of malignant thyroid neoplasms was 814 cases/year, the prevalence 84.2 diseased/100 000 people and mortality 80 patients/ year (Fig. 2) ( ref. $^{14}$ ).

Further, there are regional differences in incidence with: highest incidence reported in Hradec Králové (10.5 cases/100 000 people), and Zlín (10.4 cases/100 000 people) whereas the regions with the lowest incidence of malignant thyroid carcinomas are Moravskoslezský region (5.6 cases/100 000 people) and Liberec region (5.4 cases/100 000 people) (Fig 3).

The trend of increase in prevalence since 1990 is discernible for both sexes, while it is more pronounced for women (Fig. 4).

\section{MORTALITY}

The thyroid cancer worldwide mortality rate ranges from 0.2 to 1.2 in men and 0.4 to 2.8 in women / 100 000 people. In general, mortality is significantly lower than morbidity. Even though there are geographical differences, thyroid carcinoma mortality rate in the population does not exceed $1 \%$ (ref. ${ }^{1,3}$ ). In general, mortality is significantly lower than morbidity ${ }^{3}$. A slight decrease in the thyroid carcinoma mortality in recent decades has 

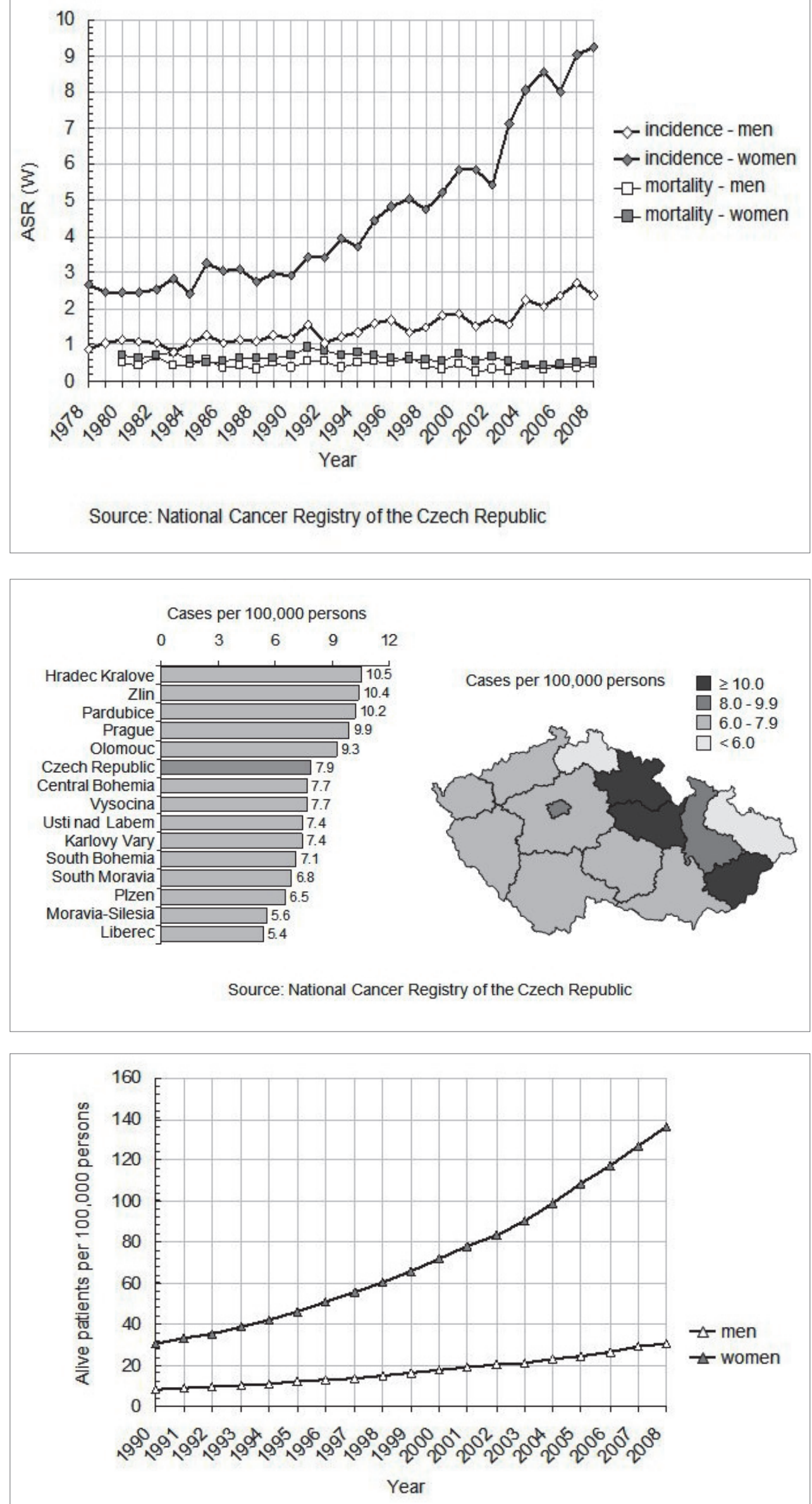

Source: National Cancer Registry of the Czech Republic
Fig. 2. Age - standardized incidence and mortality of malignant neoplasms of thyroid gland (C73), female and male population in the Czech Republic 1978- 2008. Available from: http//www. svod.cz.

Fig. 3. Incidence of malignant neoplasm of thyroid gland $(\mathrm{C} 73)$ in regions of the Czech Republic, 20042008. Available from: http// www.svod.cz.

Fig. 4. Trends of the prevalence of malignant neoplasm of thyroid gland, (C73) female and male population in the Czech Republic, 1990-2008. Available from: http//www. svod.cz. 


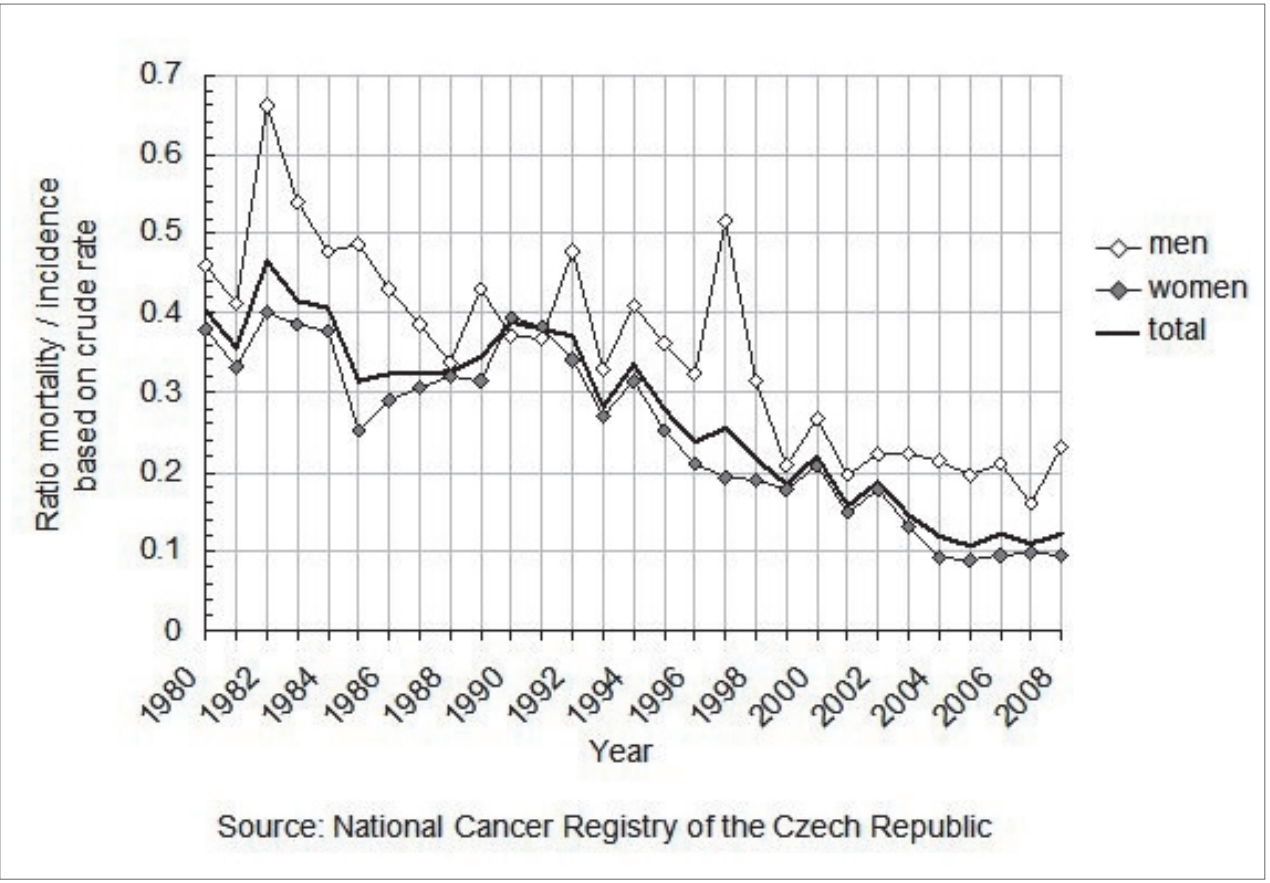

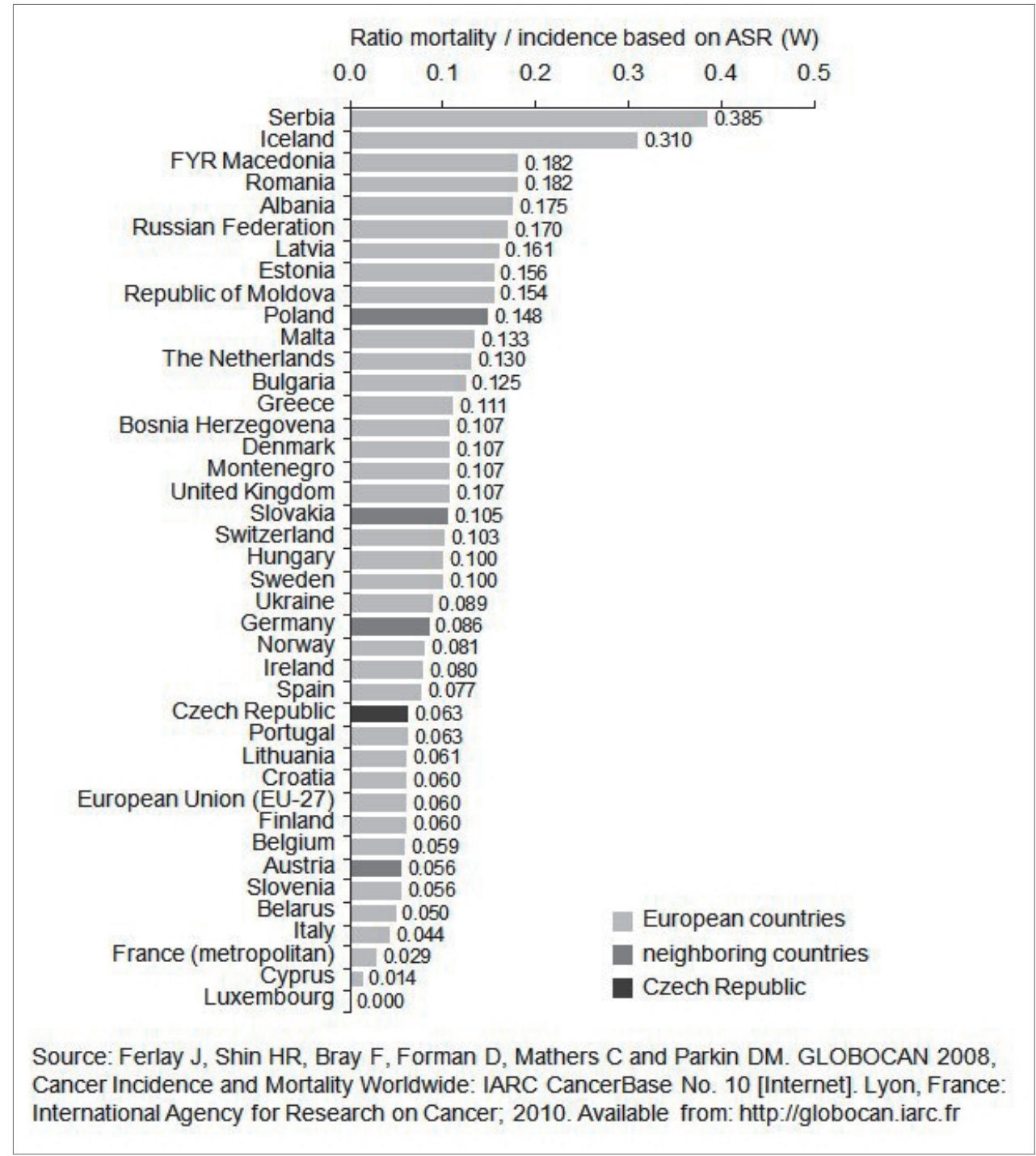

Fig. 5. Mortality to incidence ratio of malignant neoplasm of thyroid gland in the Czech Republic. Available from: http//www. svod.cz.
Fig. 6. Mortality to incidence ratio of malignant neoplasm of thyroid gland in international comparison. 
ranked the Czech Republic among countries with an average mortality (Fig. 5,6).

\section{RISK FACTORS}

Two risk factors have been proved to be connected with the development of thyroid cancers: ionizing radiation and tissue stimulation by TSH (thyroid stimulating hormone).

\section{Ionizing Radiation}

Exposure of the neck and thyroid to ionizing radiation (external or internal), x-rays or gamma radiation in a dose 10-1000 rad acts as an oncogenic factor and induces RET/PTC (Rearranged in transformation/papillary thyroid carcinomas) gene rearrangement, and to a lesser extent chromosomal inversion which leads to cell transformation. To date, twelve RET/PTC fusion genes have been identified ${ }^{15}$. The most frequent are RET/PTC1 and RET/PTC3 which cause specific nuclear morphological changes (deformities of nucleus membrane and chromatin clearing). RET/PTC1 is typical for the "spontaneous PTC”. Radiation-induced carcinomas are characterized by the RET/PTC3 gene activation which correlates with the more aggressive behavior of such cancers ${ }^{16-18}$.

Patients are exposed to ionizing radiation during the radiation treatment of malignant tumors of head and neck regions and hematological diseases. Until 1960, radiotherapy was also used for the treatment of benign diseases in children (e.g. acne vulgaris, tinea capitis, thymic hyperplasia or inflammatory diseases of head and neck). This resulted in radiation-induced damage and an increased incidence of growth, especially papillary carcinomas, with a latency period of approximately 20 years. This so-called radiogenic carcinoma affects about $10 \%$ of patients who had their neck regions exposed to radiation ${ }^{3}$.

Accidents in nuclear power stations and nuclear explosions are another cause of contamination by radionucleotides, e.g. disasters in Chernobyl in 1986 and Fukushima in 2011, atomic bomb explosions in Nagasaki and Hiroshima 1945, Bravo hydrogen bomb explosion above the Marshall Islands, Bikiny, and Eniwetok Atolls in 1946 - 1958. Children under 10 years of age are the highest-risk group. The younger the affected individual is, the higher is their radiosensitivity ${ }^{19}$. Radioactive isotopes of iodine enter the human body, depending on the distance from the epicenter, by two main routes: inhalation, perimeter $\leq 30 \mathrm{~km}$ and alimentary (especially milk) perimeter $>30 \mathrm{~km}$. The extreme uptake of radioactive iodine into the thyroid leads in the early stage, to acute radiation thyroiditis and later to autoimmune thyroiditis and hypothyrosis. In the affected areas, the thyroid carcinoma risk lasts about 30 years.

After the Chernobyl disaster, there was an extremely high incidence of thyroid cancers in children in Belarus and the Ukraine even at the end of 1990. The incidence of thyroid carcinoma in children increased more than 30 times compared to the situation prior to $1986\left(\right.$ ref. $\left.^{20}\right)$. The highest incidence was found in children, who were in 1986 $\leq 5$ years of age and who lived in areas where the radiation doses reached $\geq 0.50$ Gy (gray). Iodine deficiency made the situation even worse ${ }^{21,22}$. During the first 4 years after the Chernobyl disaster, an increase of newly diagnosed DTC from 2 to $4.6 \%$ was found in the Czech Republic. Another increase in the incidence after 1990 is basically independent of time; the interannual increase in incidence of thyroid carcinomas totals $2.6 \%$ (ref. $^{23}$ ) and is not associated directly with the Chernobyl disaster.

\section{Stimulating Effect of TSH and Other Thyroid Diseases}

Another factor stimulating thyroid cancer is prolonged increase in TSH levels leading to altered thyroid activity: immunological processes leading to the cytokine production, production of intracellular fluid as well as other growth factors and their binding proteins. Increased TSH levels also predispose to cancerogenic transformations in radiotherapy-induced damage to thyroid cells and support primary tumor growth.

Some benign thyroid diseases are associated with thyroid carcinomas. The findings of a number of authors imply that Hashimoto's thyroiditis is a predisposing factor for the occurrence of thyroid carcinomas, especially as at consequence of ineffective and prolonged conservative therapy ${ }^{3,5,7}$. The relationship between the Graves ' disease and thyroid carcinoma has also been studied but no clear correlation has been found to date $\mathrm{e}^{7,12}$.

\section{Positive Family Anamnesis}

Positive family anamnesis is found in about $3 \%$ (ref. $^{3}$ ) of people with a thyroid carcinoma. Some less familiar syndromes are associated with the presence of nodes and carcinomas, the Gardner syndrome (familial colorectal polyposis and papillary thyroid cancer and benign cutaneous and connective tissue growths). Patients with familial adenomatous colorectal polyposis are at 100 times greater risk of papillary thyroid carcinoma development than the rest of the population ${ }^{3,12}$. This disease is linked with the APC tumor suppressor gene at chromosome 5q21. Similarly, Turcot's syndrome (large intestine polyposis and breast cancer), connected with papillary and follicular thyroid cancer, is characterized by the damage to chromosome 10q22-23 (ref.,12).

\section{Environmental Influences}

Ethnic differences and dietary/environmental factors also play a role in thyroid carcinoma development, e.g. iodine and selenium deficiency. Iodine deficiency threatens almost 2 billion people, and mild deficiency can even be found in some parts of Europe, such as mountainous areas of Italy and Greece and lowland Holland. The human organism is exposed to various forms of radiation ${ }^{24}$. In the Czech Republic, lifelong exposure to radiation of the population includes internal radiation from natural radionuclides, external radiation from the earth and natural radon radiation in houses. Spontaneous radiation and the impact of volcanic environments (prevalence of basalt), with increased concentrations of various chemical elements (e.g. B, Fe, Va and ${ }^{222} \mathrm{Rn}$ ) in drinking water. Such areas are for example Iceland, Hawaii and Sicily ${ }^{25}$. See 


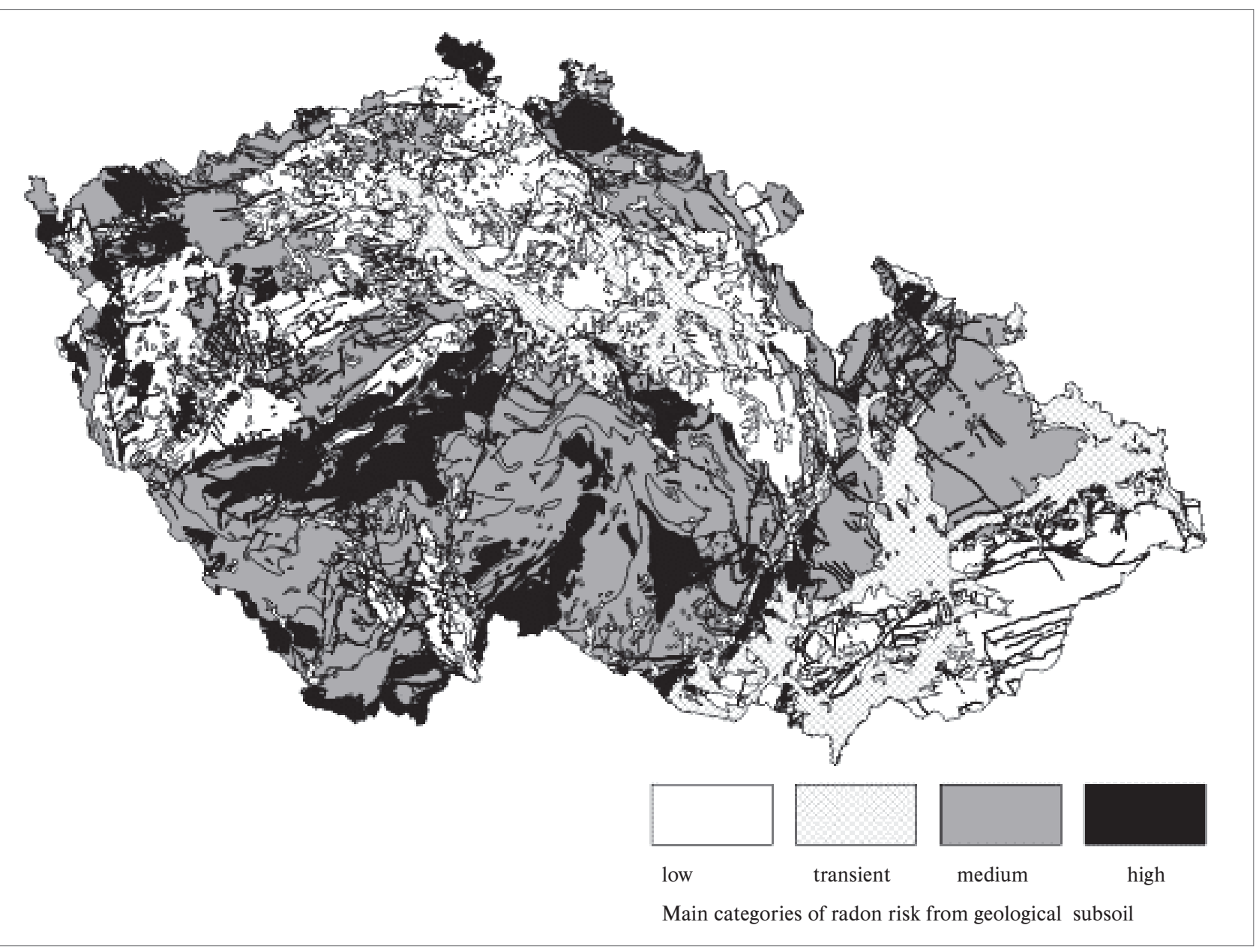

Fig. 7. Geological radon risk prognosis map of the Czech Republic. Available from: www.geologicke-mapy.cz

the geological radon risk prognosis map of the Czech Republic (Fig. 7). Pollution of the environment by polychlorinated biphenyls. Increased intake of nitrates (i.e. from green vegetables and ham) leads to increased risk of thyroid carcinoma in $\mathrm{men}^{26}$.

\section{Improved Diagnostic Methods}

The reported increased incidence of malignant thyroid carcinomas can also be ascribed to improved clinical and laboratory tests. The greater sensitivity of diagnostic methods such as, ultrasound-guided fine needle aspiration biopsy (FNAB), which enable sufficient amounts of cytological material even from tumors with a diameter of $2 \mathrm{~mm}^{27}$, and measurement of serum thyroglobulin $(\mathrm{Tg})$ in aspirated fluids, has probably contributed to the apparent dramatic increase in incidence of thyroid cancers, especially microcarcinomas (MC) $\left(\right.$ ref. $\left.{ }^{28}\right)$.

\section{PROGNOSTIC FACTORS}

\section{Tumour Factors}

\section{Histological Form of Tumors}

The histological form of the tumor is important for disease prognosis; papillary carcinoma (PTC) is a tumor with a very good prognosis and greatest survival rate.
More than $85 \%$ patients survive 40 years of age ${ }^{29}$. There are also other histological subtypes of papillary carcino$\mathrm{ma}$, and the most common is the follicular variant. In this form, the typical cellular characteristics of PTC are preserved (intranuclear inclusion and clear nuclei). Cells create microfollicles (rosettes) but lack papillary fragments, inspissated colloid and large multinuclear cells. Its clinical behavior is the same as for the papillary form.

Tall cell variant of PTC is characterized by a distinct cell shape, where the height of cells is at least double their width. The tumor is angio-invasive, spreads aggressively and tends to later loco-regional recurrence.

Insular carcinoma is a variant of FTC and is characterized by solid clusters of small follicles resembling pancreatic islets. This carcinoma is classified as a poorly differentiated carcinoma with highly aggressive behavior. Fig. 8 shows the incidence of individual forms of malignant carcinomas in the Czech Republic.

\section{Tumor Size}

The tumor size also correlates with the incidence of loco-regional and distant metastases. Mazzaferri et al. observed tumors sizes for 30 years and reported $0.4 \%\left(\right.$ ref. $\left.{ }^{30}\right)$ mortality rate in patients with tumors smaller than 1.5 $\mathrm{cm}$, compared to patients with tumors $>4.5 \mathrm{~cm}$, where the mortality was $22 \%\left(\right.$ ref. ${ }^{30}$ ). 


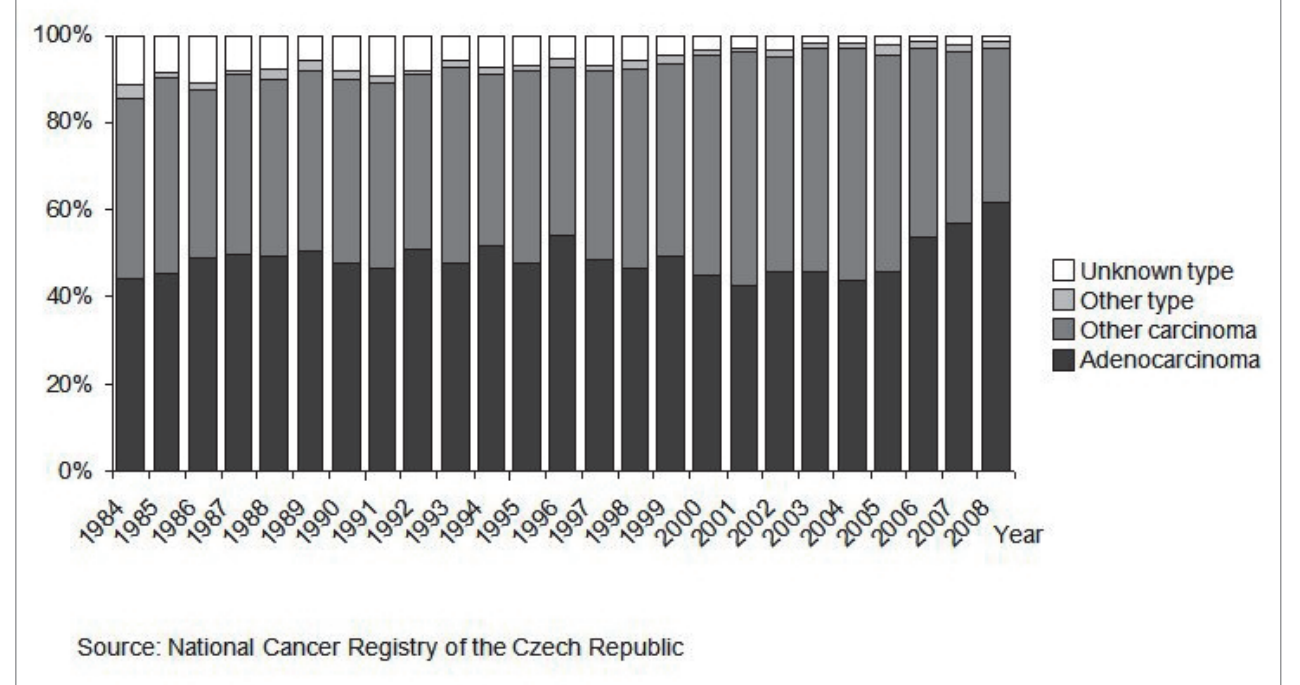

Fig. 8. Types of malignant neoplasms of the thyroid in the Czech Republic, 20042008.

Available at: http//www. svod.cz

\section{Lymph Node Metastases}

There has been a lot of discussion regarding the significance of loco-regional lymph node metastases. Some studies imply that the presence of lymph node metastases does not have any impact on the prognosis ${ }^{31,32}$. In contrast, other authors consider the presence of lymph node metastases a negative prognostic factor, especially in the case of bilateral and contralateral cervical lymph node metastases ${ }^{33-35}$. The prognosis in the case of affected nodes depends on the age, when the disease manifested. Local metastases into cervical lymph nodes in patients under 40 years of age do not influence their survival rate, whereas in patients over 40 years of age metastases into cervical lymph nodes mean an unfavorable prognosis ${ }^{1,3}$.

\section{Extrathyroidal Extension}

At the time of diagnosis, extrathyroidal extension is revealed in more than $30 \%$ (ref. ${ }^{30}$ ) of patients with PTC. Local invasion can affect surrounding muscles, esophagus, trachea, blood vessels, and neural structures. Even microscopic spread of a tumor through the gland capsule is connected with a higher risk of recurrence and higher probability of metastases into cervical lymph nodes. The larger the tumor the higher is the probability of local in$\operatorname{vasion}^{31,35}$.

\section{Distant Metastases}

Distant metastases occur in about $10 \%$ (ref. ${ }^{30}$ ) of patients with PTC and FTC: Fortunately, only half of them are present initially. Distant metastases are the main cause of death ${ }^{30}$. They are mainly located in the lungs and bones. Most patients develop distant metastases in the lungs; over 50\% (ref. ${ }^{36}$ ) have this involvement alone, $25 \%\left(\right.$ ref $^{36}$ ) have bone involvement alone, $20 \%$ (ref. ${ }^{36}$ ) have both lung and bone involvement and about 5\% (ref. ${ }^{36}$ ) develop distant metastases in other sites.

\section{Oncogenes}

The study of oncogenes and their ability to predict the clinical behaviour of thyroid cancers has been intensively investigated. The most studied of these oncogenes, is the $\mathrm{B}$ raf proto-oncogene (BRAF). The clinical significance of the mutation in terms of patient outcome is controversial. Elisei et al. and others reveals a significant correlation with the worst outcome for patients with PTC. The presence of a BRAF mutation is associated with extrathyroidal invasion, multicentricity, nodal metastases, higher-stage disease, older age at initial presentation, and higher likelihood of recurrent or persistent disease ${ }^{37,38}$. Conversely, other studies have not shown any significant relationship between the presence of a BRAF mutation and clinical outcome ${ }^{39}$.

\section{Patient Variables \\ Gender}

Thyroid diseases affect women 8-10times more often than men. More frequent diagnostics of tumors is probably connected with their higher incidence and also with a more frequent diagnosis of thyropathy. Women significantly outnumber men 4:1 in incidence of thyroid carcinomas. A decreased in thyroid function affects about 4-5 $\%$ of women of fertile age and about $10-15 \%$ of examined women over 65 (ref. ${ }^{1-3}$ ). Thyrotoxicosis is diagnosed in $1 \%$ $\left(\right.$ ref. $^{3}$ ) of the adult population, again more often in women. The disease etiology changes with age; a younger age it has immunogenic character (Graves 'disease), and in the elderly population thyrotoxicosis is based on thyroid tissue autonomy (toxic nodular goiter, toxic adenoma). However, in men the tumours are substantially more aggressive $^{2,3,10}$.

\section{Age}

At the time of diagnosis, age is a main independent prognosis indicator. After the age of 40, recurrence and mortality rates increase linearly. Older patients have locally more aggressive growths, more aggressive histological forms of carcinomas and higher incidence of distant metastases. Further, patients over 65 have worse dosimetric parameters of radioactive iodine accumulation ${ }^{3}$.

Kumar et al. proved that PTC in children under 10 years of age is also more aggressive, with loco-regional metastases in $83 \%$ of cases and distant metastases in $67 \%$ $\left(\right.$ ref. $\left.{ }^{40}\right)$. In the Czech Republic, the average age of patients 

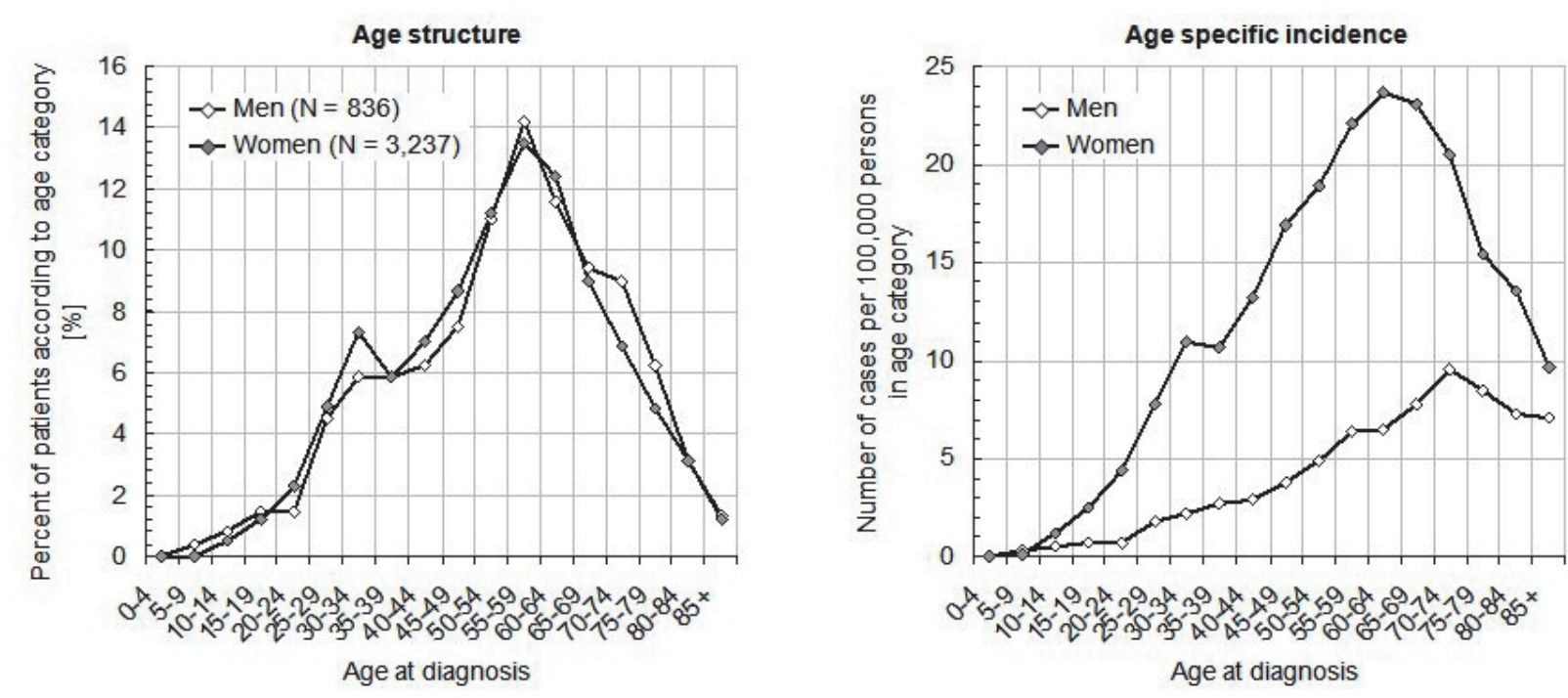

\begin{tabular}{lccc}
$\begin{array}{l}\text { Age at diagnosis } \\
\text { (years) }\end{array}$ & $\begin{array}{c}\text { Men } \\
\mathrm{N}=836\end{array}$ & $\begin{array}{c}\text { Women } \\
\mathrm{N}=3,237\end{array}$ & $\begin{array}{c}\text { Total } \\
\mathrm{N}=4,073\end{array}$ \\
\hline Mean & 54 & 53 & 53 \\
Median & 57 & 55 & 55 \\
Minimum & 5 & 9 & 5 \\
Maximum & 92 & 96 & 96 \\
$25^{\text {th }}$ percentile & 43 & 42 & 42 \\
$75^{\text {th }}$ percentile & 66 & 65 & 65
\end{tabular}

Source: National Cancer Registry of the Czech Republic

Fig. 9. Age of patients with malignant thyroid neoplasms in the Czech Republic, 2004-2008. Available at: http//www.svod.cz

with a malignant thyroid neoplasm is 53 years, median 55 and range 5-96 years (Fig. 9).

\section{Tumor Staging System}

Determination of the disease stage according to TNM is necessary for a good assessment of prognosis. Unfavorable findings, which increase the disease stage, are tumor size over $4.5 \mathrm{~cm}$, spread outside the thyroid capsule, presence of distant metastases at the time of diagnosis, and age over 40 . This has a significant impact on the proposed therapy, especially the scope of surgery. In patients at advanced stages, there is $50 \%$ (ref. $^{3}$ ) risk of death within 15 years. Advanced carcinoma stages are more often found in men (Fig. 10).

In the last decade, there has been a significant increase in the number of newly diagnosed small thyroid carcinomas, which are reported as microcarcinoma (PTMC) $($ ref.1-3,41 $)$. These carcinomas are $\leq 20 \mathrm{~mm}$ in size. They represent minimum risk, and constitute $53 \%$ of all malignant thyroid cancers. They have almost no biological activity. For this reason, the prognosis is favorable. Nevertheless, most authors regard such microcarcinomas as clinically significant lesions, especially if they are multifocal and affect both lobes (bilateral finding). They can threaten the patient by a local growth and by the occurrence of regional or distant metastases ${ }^{38}$.

\section{Extent of Surgery}

There is no uniform opinion on the extent of surgery in the case of PTMC. Most surgeons consider hemithyroidectomy with subsequent postoperative substitution adequate in the case of monofocal PTMC without metastases into regional cervical lymph nodes. Total thyroidectomy is required in the case of multifocal PTMC or tumors of higher TNM stage. This surgery allows postoperative optimization using the I-131 therapy, easier monitoring of the disease on the thyroglobulin levels, decrease in loco-regional recurrence, and improved prognosis ${ }^{31,33,42}$.

\section{CONCLUSION}

The incidence thyroid cancer has been steadily growing in the Czech Republic. Since the beginning of the 1980s it has increased four times. Compared with other European countries, it is classed as a country with a high incidence. At the same time it is ranked among countries with average and decreasing mortality. Obviously, the improved detection methods do not explain the growing incidence. There are a number of reasons for the trends, such as improved diagnostic techniques using ultrasound and FNAB and more radical surgery. There are also dietary/environmental factors such as - iodine deficiency and to a lesser extent selenium deficiency, the influence 


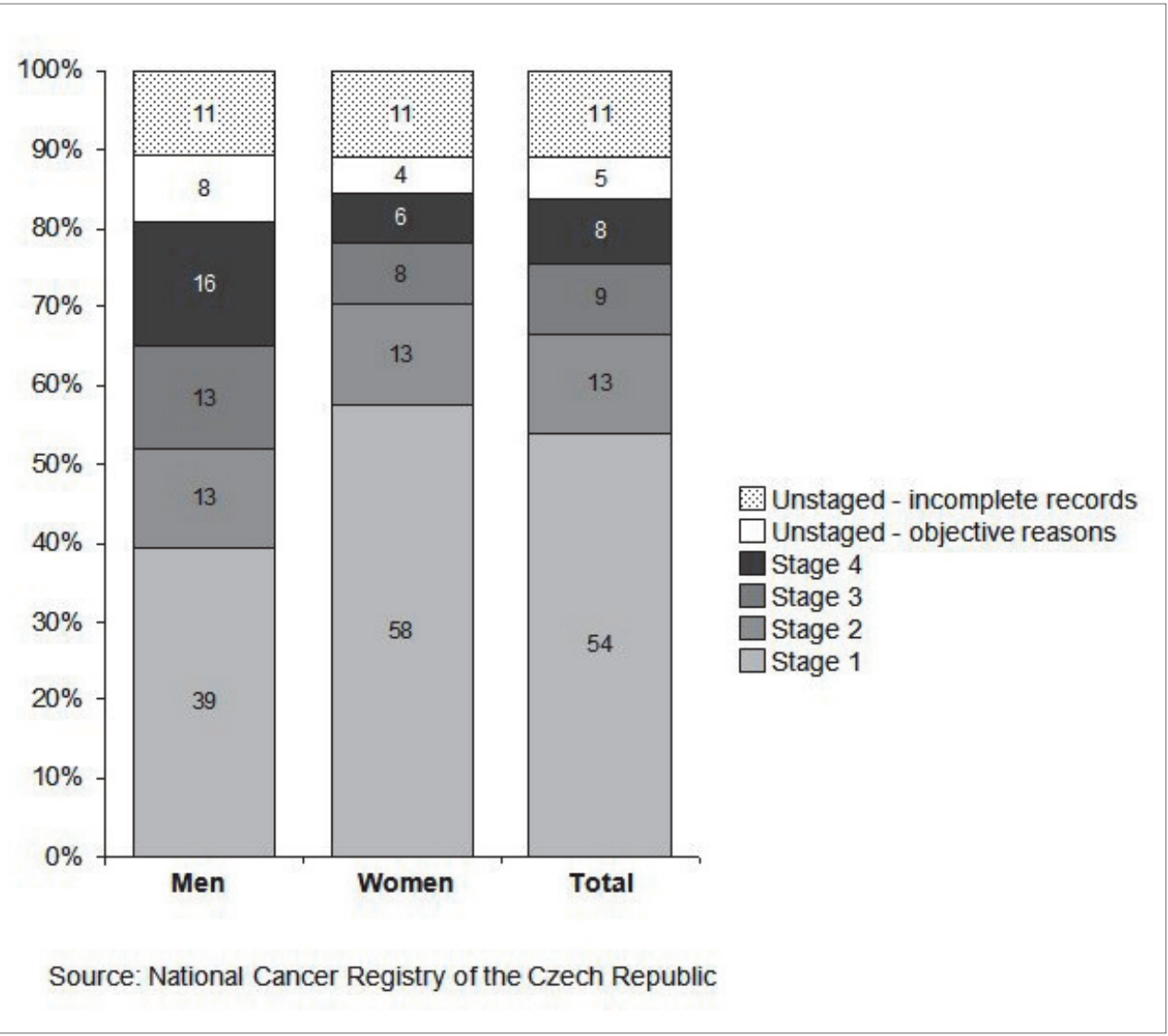

Fig. 10. Stage of disease of malignant thyroid neoplasm in male and female population. Available at: http// www.svod.cz of nitrates, polychlorinated biphenyls, increased ionizing radiation, and prolonged increase in TSH. The prognosis of patients with DTC also depends on the age at the time of diagnosis. A favorable prognosis also depends on timely detection.

\section{CONFLICT OF INTEREST STATEMENT}

Author's conflict of interest disclosure: The authors stated that there are no conflicts of interest regarding the publication of this article.

\section{REFERENCES}

1. Sipos JA, Mazzaferri EL. Thyroid cancer epidemiology and prognostic variables. Clin Oncol (R Coll Radiol) 2010;22:395-404.

2. Becker HD, Hohenberger W, Junginger T, Schlag PM. Chirurgická onkologie. 1 ed. Prague Grada Publishing, a.s., 2005.

3. Vlček P. Tumours thyroid gland. Postgraduální medicína 2007;9:1904.

4. Nagaiah G, Hossain A, Mooney CJ, Parmentier J, Remick SC. Anaplastic thyreoid cancer: A review of epidemiology, pathogenesis and treatment. J of Oncology 2011;2011:542358.

5. Pederesen RK, Pederesen NT. Primary non-Hodgin's lymphoma of the thyroid gland: a population based study. Histopathology 1996;28:25-32.

6. Čáp J, Ryška A. Fine-needle aspiration biopsy of the thyroid gland. Hradec Králové: Nucelus HK, 2003;178 s.

7. Kilfoy BA, Zheng T, Holford TR, Han X, Ward MH, Sjodin A. International patterns and trends in thyroid cancer incidence, 19732002. Cancer Causes Control 2009;20:525-31.
8. Davies L, Welch HG. Increasing incidence of thyroid cancer in the United States, 1973-2002. Jama 2006;295:2164-7.

9. Aschebrook-Kilfoy B, Ward MH, Sabra MM, Devessa SSilfo. Thyroid cancer incidence patterns in the United States by histologic type, 1992-2006. Thyroid 2011;21:125-34.

10. Ferlay J, Shin HR, Bray F, Forman D, Mathers C, Parkin DM. GLOBOCAN 2008: Cancer Incidence and Mortality Worldwide. IARC Cancer Base No. 10. Lyon: IARC 2010. [cited 2010 Sep 22]. Available from: http:// globocan.iarc.fr.

11. Dvořák J. Thyroid carcinoma. Praha: Libri; 1997, 303 s.

12. Limanová Z. Thyroid carcinoma - diagnosis and treatment. Interní medicína pro praxi 2003;6:308-14.

13. Pačesová P. Thyroid cancer and malignant lymphoma- is there relationship? Praktický lékař 2007;87:178-81.

14. Dušek L, Mužík J, Kubásek M, Koptíková J, Žaloudík J, Vyzula R. Epidemiology of malignant tumours in the Czech Republik [online]. Masaryk University 2005 [cited 2008 Dec 15]. Available from: http:// www.svod.cz.

15. Fagin JA, Mitsiades N. Molecular patology of thyroid cancer: diagnostic and clinical implications. Best Pract\&Res Clin Endocrinol\&Metab 2008;22(6):955-69.

16. Feinberg AP, Ohlsson $R$, Henikoff $S$. The epigenetic progenitor origin of human cancer. Nat Rev Genet 2006;7:21-33.

17. Nekulová $M$, Šimíčková $M$, Valik O. Tumor markers and epigenetic factors. Klinická biochemie a metabolismus 2006;14:152-6.

18. Powell JG, Hay ID. Papillary carcinoma of the thyroid. In: Randolph $\mathrm{GW}$, editor. Surgery of the thyroid and parathyroid glanc. Philadelphia: Elsevier Science;2003, p.188-209.

19. Cardis E, Hatch M. The Chernobyl accident - an epidemiological perspective. Clin Oncol (R Coll Radiol) 2011;23:251-60.

20. Kazakov VS, Demidchik EP, Astakhova LN. Thyroid cancer after Chernobyl. Nature 1992;359:21-3.

21. Likhatov I, Kovgan L, Vavilov S, Chepurny M, Bouville A, Luckyanov $\mathrm{N}$, Jacob P, Voillequ AP, Voigt G. Post-Chernobyl thyroid cancers in Ukraine. Report 1: estimation of thyroid doses. Radiat Res 2005;163:125-36.

22. Williams ED, Pacini F, Pinchera A. Thyroid cancer following Chernobyl. J Endocrinol Invest 1995;18:144-6. 
23. Kolektiv autorů. Patnáct let od havárie Černobylu - důsledky a poučení. Praha: SUJB, 2001; http://www.subj.cz

24. Wartofsky L. Increasing world incidence of thyroid cancer. Increased detection or higher radiation exposure? Hormones 2010;9(2):103-8.

25. Pellegriti G, De VF, Scollo C, Attard M, Giordano C, Arena S, Dardanoni $\mathrm{G}$, Vigneri R. Papillary thyroid cancer incidence in the volcanic area of Sicily. J Natl Cancer Inst 2009;101:1575-83.

26. Ward MH, Kilfoy BA, Weyer PJ, Anderson KE, Folsom AR, Cerhan JR. Nitrate intake and the risk of thyroid cancer and thyroid disease. Epidemiology 2010;21:389-95.

27. Sigurdson AJ, Ronckers CM, Mertens AC, Stovall M, Smith SA, Liu Y. Primary thyroid cancer after a first tumour in childhood (the Childhood Cancer Survivor Study): a nested case-control study. Lancet 2005;365:2014-23.

28. Yang GC, LiVolsi VA, Baloch ZW. Thyroid microcarcinoma: fine-needle aspiration diagnosis and histologic follow-up. Int J Surg Pathol 2002;10:133-9.

29. Němec J, Chytrý $P$, Dvořák J, Vlček $P$, Neradilová $M$, Racek $P$, Blažek $T$, Zeman V. Effect of sex on the prevalence and survival in thyroid carcinoma.Vnitř lék 1996;42:602-4.

30. Mazzaferri EL. Management of low-risk differentiated thyroid cancer. Endocr Pract 2007;13:498-512.

31. Shaha AR, Shah JP, Loree TR. Risk group stratification and prog nostic factors in papillary carcinoma of thyroid. Ann Surg Oncol 1996;3:534-8.

32. Bhattacharyya N. A population-based analysis of survival factors in differentiated and medullary thyroid carcinoma. Otolaryngol Head Neck Surg 2003;128:115-23.

33. Ito Y, Higashiyama T, Takamura Y, Miya A, Kobayashi K, Matsuzuka F, Kuma K, Miyauchi A. Risk factors for recurrence to the lymph node in papillary thyroid carcinoma patients without preoperatively detect- able lateral node metastasis: validity of prophylactic modified radial neck dissection. World J Surg 2007;31:2085-91.

34. Podnos YD, Smith D, Wagman LD, Ellenhorn JD. The implication of lymph node metastasis on survival in patients with well-differentiated thyroid cancer. Am Surg 2005;71:731-4.

35. Lee SH, Lee SS, Jin SM, Kim JH, Rho YS. Predictive factors for centra compartment lymph node metastasis in thyroid papillary microcarcinoma. Laryngoscope 2008;118:659-62.

36. Lee J, Soh EY. Differentiated thyroid carcinoma presenting with distant metastasis at initial diagnosis: clinical outcome and prognostic factors. Ann Surg 2010;251:114-9.

37. Elisei R, Ugolini C, Viola D, Lupi C, Biagini A, Giannini R, Romei C, Miccoli P, Pinchera A, Basolo R. BRAF (V E) station and outcome of patiens with papillary thyroid carcinoma: 15-year median follow-up study. J Clin Endocrinol Metab 2008;93:3943-9.

38. Lupi C, Giannini R, Ugolini C, Proietti A, Berti P, Minuto M, Materazzi G. Association of BRAF V600E mutation with poor clinicopathological outcomes in 500 consecutive cases of papillary thyroid carcinoma. J Clin Endocrinol Metab 2007;92:4085-90.

39. Brzezianska E, Pastuszak-Lewandoska D, Wojciechowska K, Migdalska-Sek M, Cyniak-Magierska A, Nawrot E, Lewinski A. Investigation of V600E BRAF station in papillary thyroid carcinoma in the Polish population. NeuroEndocrinol Lett 2007;28:351-3.

40. Kumar A, Bal CS. Differentiated thyroid cancer. Indian J Pediatr 2003; 70:707-713.

41. Elaraj $\mathrm{DM}, \mathrm{Clark} \mathrm{OH}$. Changing management in patiens with papillary toroid cancer. Curr Treat Options Oncol 2007; 8(4):305-313.

42. Bilimoria $K Y$, Bentrem DJ, Ko $C Y$, Stewart AK, Winchester DP, Talamonti MS, Sturgeon A. Extent of Sumery affects survival for papillary thyroid cancer. Ann Surg 2007; 246:375-381. 